\title{
Sensitive and selective detection of DNA fragments associated with Ganoderma boninense by DNA- nanoparticle conjugate hybridisation
}

\author{
Ekta Rani ${ }^{1}$, Siti Akhtar Mohshim ${ }^{2,3}$, Nor Hidayat Yusof ${ }^{4}$, Muhammad Zamharir Ahmad ${ }^{2}$, \\ Royston Goodacre ${ }^{1,5}$, Shahrul Ainliah Alang Ahmad ${ }^{3,4}$, and Lu Shin Wong ${ }^{1, *}$ (1)
}

\footnotetext{
${ }^{1}$ Manchester Institute of Biotechnology and School of Chemistry, University of Manchester, 131 Princess Street, Manchester M1 7DN, UK

${ }^{2}$ Biotechnology and Nanotechnology Research Centre, Malaysian Agricultural Research and Development Institute, 43400 Serdang, Selangor, Malaysia

${ }^{3}$ Institute of Advanced Technology, Universiti Putra Malaysia (UPM), 43400 Serdang, Selangor, Malaysia

${ }^{4}$ Department of Chemistry, Faculty of Science, Universiti Putra Malaysia, 43400 Serdang, Selangor, Malaysia

${ }^{5}$ Department of Biochemistry, Institute of Integrative Biology, University of Liverpool, Crown Street, Liverpool L69 7ZB, UK
}

Received: 4 May 2020

Accepted: 5 July 2020

Published online:

20 July 2020

(C) The Author(s) 2020

\begin{abstract}
A colourimetric assay for the detection of DNA fragments associated with the oil palm pathogen Ganoderma boninense and other fungi DNA is reported. The assay is based on the aggregation of DNA-nanoparticle conjugates in the presence of complementary DNA from the target organism. Here, various designs of DNAnanoparticle conjugates were evaluated, and it was found that the best design gave a visually observable colour change with as little as 2 pmol of doublestranded DNA analyte even in the presence of a large excess of a mixture of noncomplementary DNA. Overall, this label-free system is rapid, sensitive, selective, simple in design, and easy to carry out. It does not require specialist equipment or specialist training for the interpretation of the results, and therefore has the potential to be deployed for agricultural diagnostics in the field.
\end{abstract}

Address correspondence to E-mail: 1.s.wong@manchester.ac.uk 


\section{GRAPHIC ABSTRACT}

Development of a colourimetric assay based on DNA-nanoparticle conjugates for the oil palm pathogen Ganoderma boninense.

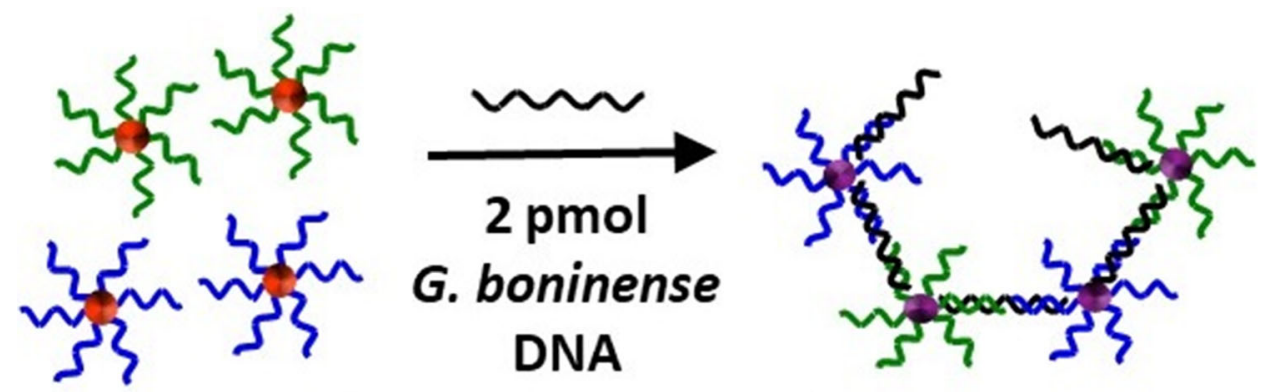

Negative: Red

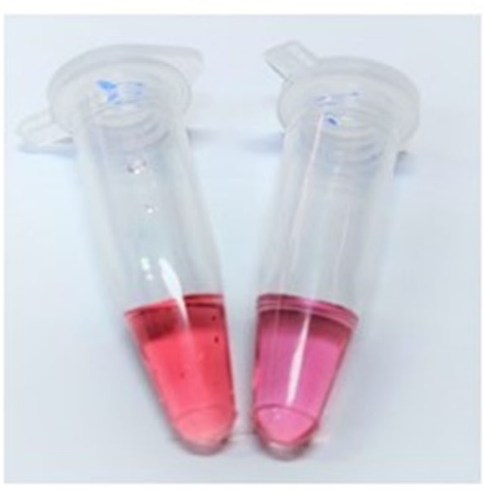

Positive: Lilac

\section{Introduction}

The oil palm Elaeis genesis is the most important cash crop in Malaysia, which generated an annual export income of RM 65 billion ( US\$ 16 billion) in 2016 [1]. However, the yearly harvest is substantially reduced by basal stem rot (BSR) disease, caused by infections of pathogenic fungi of the Ganoderma sp., and in particular Ganoderma boninense [2-6]. BSR causes a reduction in crop yields and eventual death of the palms, necessitating frequent felling and replanting. As a result, BSR causes economic losses of between RM 225 million and RM 1.5 billion annually in Malaysia alone [7]. Since there is no effective treatment for BSR once it manifests, management of the disease revolves around the isolation of infected plants (e.g. by trenching, ploughing, or harrowing the soil around the palm) [2]. As with any transmissible disease, early detection of infection is key to this management strategy. However, such detection is currently difficult since Ganoderma is a soil-borne organism that is transmitted through the roots of young plants, and the disease is symptomless at the early stage of infection. Thus, there is a need for quantitative, sensitive, and selective detection methods. Furthermore, for any diagnostic system to be applicable for use in the field, it must also ideally be portable, affordable, have low power consumption, be tolerant to a wide range of environmental conditions, and not dependent on specialist equipment or training.

Various physical and chemical methods based on volatile molecule "electronic-nose" sensors [8], ultrasonic density measurements [9], spectral imaging [10-12], and microwave radar backscattering [13] have been investigated in attempts to detect G. boninense in the field. However, these detection methods possess practical disadvantages regarding complexity, cost and the need for specialist equipment and training to interpret the data. From a molecular biological perspective, the earliest molecular attempts to identify $G$. boninense species relied on antibody-based 
immunoassays [14-16]. However, due to the crossreactivity of the antibodies, false-positive results caused by other fungi such as Trichoderma and Botrytis species, were also observed [15]. Further, their application in routine analysis is limited by their complex protocols, labile reagents with high cost, relatively low sensitivity, and the requirement of highly skilled personnel. Electrochemical methods for the detection of quinoline (a secondary metabolite produced by the palms under Ganoderma attack) [17] and DNA fragments associated with this organism $[18,19]$ have also been reported. The latter, in particular, has been shown to give high sensitivity $(5 \mathrm{~mL}$ of analyte at $\sim 1 \mathrm{fM}$ of target DNA) and selectivity towards G. boninense. However, these methods rely on electrodes that are somewhat complex to fabricate and still rely on trained personnel for data analysis and interpretation.

In contrast, colourimetric assays that employ gold nanoparticles (AuNP) conjugated to DNA [20-28] have shown great potential in diagnostics for human diseases [29, 30]. Here, the presence of an analyte DNA strand bearing a sequence complementary to the DNA on the AuNP results in hybridisation of the DNA and concomitant aggregation of the nanoparticles. This aggregation gives rise to an increase in the particles' surface plasmon resonance and thus UVVis absorption spectrum (i.e. an increase in $\lambda_{\max }$ of the spectrum), which translates into a visually observable colour change (typically red to lilac). Indeed, visible colour changes upon nanoparticle aggregation have been used in other areas, including trace metal analysis in water testing [31]. This analytical approach, therefore, offers many of the attributes that are desirable in a diagnostic system and would be applicable to field use, being portable, easy to carry out (only simple manipulations and without specialist equipment), and interpret.

Herein, we report a methodology for the application of DNA-AuNP conjugates towards the detection and quantification of DNA sequences related to $G$. boninense and other fungal DNA, in the context of single- and double-stranded DNA analytes, as well as in the presence of a mixture of non-complementary DNA. Furthermore, these procedures have been carried out independently in the UK (Manchester) and Malaysia (UPM) to demonstrate their reproducibility.

\section{Materials and methods}

\section{Materials and equipment}

All chemical reagents were purchased from SigmaAldrich (now Merck) or ThermoFisher Scientific and used as supplied. All reagents were of analytical grade. 20-nm AuNP colloid at a concentration of 1 optical density (OD) unit @ $525 \mathrm{~nm}$ in $0.1 \mathrm{mg} \mathrm{mL}^{-1}$ sodium citrate was purchased from Alfa Aesar (Heysham, UK). Deionised water (resistivity $\sim 18.2 \mathrm{M} \Omega$ ) was used in all cases.

The single-stranded (ss) DNA, double-stranded (ds) DNA of the analyte sequences and various DNA probes (with a $5^{\prime}$ S-S C6 disulfide linker or 3' S-S C3 disulfide linker) were purchased from SigmaAldrich. These were supplied after purification by high-performance liquid chromatography and in lyophilised form. Deoxyribonucleic acid sodium salt from calf thymus (referred henceforth as "CT") was supplied by Sigma-Aldrich.

\section{Preparation of DNA-AuNP conjugates}

The DNA-AuNP conjugates were prepared using a general procedure previously described [32] with few modifications. Aqueous solutions of disulfide-functionalised oligonucleotides $(100 \mu \mathrm{M}, 40 \mu \mathrm{L})$ and tris(2-carboxyethyl)phosphine $(20 \mathrm{mM}, 40 \mu \mathrm{L})$ were combined and incubated for $2 \mathrm{~h}$ at room temperature (RT) to prepare $50 \mu \mathrm{M}$ solutions of the oligonucleotides with reduced thiols. This solution $(80 \mu \mathrm{L})$ was then mixed with $1 \mathrm{~mL}$ of citrate stabilised AuNP colloid, and the mixture was incubated at RT for $12 \mathrm{~h}$. $24 \mu \mathrm{L}$ of $1 \mathrm{M} \mathrm{NaCl}$ was added to this mixture, followed by sonication for $10 \mathrm{~s}$. The $\mathrm{NaCl}$ addition and sonication were repeated four times at $1 \mathrm{~h}$ intervals (i.e. 5 times in total) until a final concentration of $0.1 \mathrm{M} \mathrm{NaCl}$ was achieved. The final colloidal solution was allowed to stand at RT for $24 \mathrm{~h}$ and then centrifuged at $19000 \mathrm{~g}$ for $30 \mathrm{~min}$. The supernatant was decanted, and the pellet of AuNP resuspended in phosphate-buffered saline (PBS) diluted to halfstrength (i.e. final composition $5.9 \mathrm{mM}$ phosphate buffer, $68.5 \mathrm{nM} \mathrm{NaCl}, 1.35 \mathrm{mM} \mathrm{KCl}, \mathrm{pH} 7.4$ ) containing $0.01 \% \mathrm{v} / \mathrm{v}$ Tween 20 . This process of centrifugation, decanting, and resuspension was carried out three times in total, with the final pellet of AuNP being re-suspended in $100 \mu \mathrm{L}$ of $10 \mathrm{mM}$ PBS buffer. The OD was then measured by UV-Vis spectroscopy 
at $525 \mathrm{~nm}$. These DNA-AuNP conjugates were typically stored at $4{ }^{\circ} \mathrm{C}$ and used within a week of preparation. Prior to use, the OD of each colloid was adjusted to 0.7 by the addition of the relevant volume of PBS.

\section{Hybridisation assay}

Lyophilised analyte ssDNA and dsDNA were reconstituted in water to make up two stock solutions of either 5 or $1 \mu \mathrm{M}$. The more concentrated stock solution was used in experiments requiring a higher analyte final concentration of 200 pmol, while the more dilute solution was used for all other experiments.

\section{Assays with ssDNA}

$40 \mu \mathrm{L}$ of each DNA-AuNP conjugate was mixed with $10 \mu \mathrm{L}$ of hybridisation buffer $(10 \mathrm{mM}$ phosphate buffer, pH 7.0 with $0.3 \mathrm{M} \mathrm{NaCl}$ ). The analyte ssDNA stock solutions were then added in volumes appropriate to make up the desired analyte final concentration. To these mixtures, $40 \mu \mathrm{L}$ of $\mathrm{NaCl}$ solution of $5 \mathrm{M}$ was added (to achieve a final concentration of $1 \mathrm{M}$ in the assay mixture). Finally, water was added to make up the final assay volume to $200 \mu \mathrm{L}$. This assay mixture was heated to $95^{\circ} \mathrm{C}$ for $2 \mathrm{~min}$, followed by gradual cooling (approximate rate of cooling was $\left.5{ }^{\circ} \mathrm{C} \mathrm{min}{ }^{-1}\right)$ to RT $\left(25-30{ }^{\circ} \mathrm{C}\right)$ over approximately $15 \mathrm{~min}$.

\section{Assays with dsDNA}

To prepare the working analyte solutions, the dsDNA stock solutions (at volumes to make up the desired analyte concentration in $200 \mu \mathrm{L}$ ) were diluted with water to a total volume of $70 \mu \mathrm{L}$. These mixtures were heated at $95{ }^{\circ} \mathrm{C}$ for $2 \mathrm{~min}$, and to this heated solution, a mixture of DNA-AuNP conjugates $(40 \mu \mathrm{L}$ each) and $10 \mu \mathrm{L}$ of hybridisation buffer (see above for composition) was added. To these mixtures, $40 \mu \mathrm{L}$ of $\mathrm{NaCl}$ solution of either 5.0 or $6.1 \mathrm{M}$ was added to achieve a final $\mathrm{NaCl}$ concentration in the assay mixture of 1 , or $1.2 \mathrm{M}$, respectively, and a final volume of $200 \mu \mathrm{L}$. This assay was again heated at $95{ }^{\circ} \mathrm{C}$ for $2 \mathrm{~min}$, followed by gradual cooling to RT over approximately $30 \mathrm{~min}$.

\section{Detection of dsDNA in a mixture of calf-thymus DNA}

To prepare the working analyte solutions, the dsDNA stock solutions (at volumes to make up the desired analyte concentration in $200 \mu \mathrm{L}$ ) were mixed with water to a volume of $68 \mu \mathrm{L} .2 \mu \mathrm{L}$ of calf-thymus DNA solution ( $100 \mathrm{mg} / 77 \mu \mathrm{L}$ in water) was added. The rest of the procedure was followed as noted in "Assays with dsDNA" section

\section{Results and discussion}

\section{Preparation and stability of DNA-AuNP conjugates}

As targets for detection, 35-base DNA sequences from the internal transcribed spacer 1 (ITS1) region of fungal $18 \mathrm{~S}$ ribosomal genes were chosen. For the species-selective detection of $G$. boninense, the target sequence was taken from a gene bearing the NCBI GenBank accession number EU701010 [5] (termed T1, Table 1). A second sequence taken from the accession number BD082757 [5, 33] (termed T2) was also chosen, which was a match not only to $G$. boninense but also a wider range of fungal ITS1 genes and served as a more general target for the detection fungi of the Basidiomycota phylum [34].

Pairs of DNA-AuNP conjugates bearing complementary probe DNA sequences to each target were prepared. Two general assay configurations were investigated for each target. In the "head-to-tail" (HTT) [20] configuration, two probes in series were employed, with each complementary probe sequence attached at $5^{\prime}$-end to the AuNP via a 12 base GC repeat spacer and an alkylthiol linker (Fig. 1a). Here, a GC spacer [35] is used to increase the distance between the AuNPs and the target complementary DNA sequences, to address potential steric crowding during hybridisation. In the "tail-to-tail" (TTT) format [22], one probe sequence was attached at the $5^{\prime}$-end and the other via the $3^{\prime}$-end, and the DNA sequences were attached directly to the AuNPs via alkylthiol linkers only (Fig. 1b).

To improve the likelihood of identifying probes that would give reliable results, several pairs of DNA-AuNP conjugate probes were prepared for both target sequences. Thus, for target sequence T1, one probe pair in the head-to-tail configuration (termed $\mathrm{P} 1 \mathrm{a}^{\mathrm{HTT}}$ and $\mathrm{P} 1 \mathrm{~b}^{\mathrm{HTT}}$ ) and two pairs in tail-to-tail 
Table 1 List of DNA sequences used in this study. All the sequences are listed in the $5^{\prime}$ to $3^{\prime}$ direction. The colour coding is used for clarity and is consistent with that in Fig. 1. The mismatches are underlined for emphasis

\begin{tabular}{|c|c|c|}
\hline Ref. & Description & Sequence (annotated for clarity) \\
\hline T1 & $\begin{array}{l}\text { 35-mer sequence } \\
\text { corresponding to } \\
\text { fragment from } \mathrm{NCBI}\end{array}$ & TTGGCTCTCGCATCGATGAAGAAGAACGCAGCAGG \\
\hline & $\begin{array}{l}\text { GenBank accession } \\
\text { number EU701010 }\end{array}$ & \\
\hline M1 & $\begin{array}{l}\text { T1 with single a } \\
\text { mismatch }\end{array}$ & TTGGCTCTCGCATCGAT스AAGAAGAACGCAGCAGG \\
\hline $\begin{array}{l}\text { P1a } \\
\text { P1 } 1 b^{\text {HTT }}\end{array}$ & $\begin{array}{l}\text { DNA probes } \\
\text { complementary to } \mathrm{T} 1 \\
\text { in a head-to-tail } \\
\text { configuration }\end{array}$ & $\begin{array}{l}\text { Alkylhiol linker Poly-GC Binding sequence } \\
\text { (Thiol-C6)GGCCGCGGGCGGCCTGCTGCGTTCTTCTTCAT } \\
\text { (Thiol-C6)GGCCGCGGGCGGCGATGCGAGAGCCAA }\end{array}$ \\
\hline $\begin{array}{l}\text { P1a } \\
\text { P16T } \\
\text { P1T } \\
\text { P1 } \mathbf{c}^{T T T}\end{array}$ & $\begin{array}{l}\text { DNA probes } \\
\text { complementary to } \mathrm{T} 1 \\
\text { in a tail-to-tail } \\
\text { configuration }\end{array}$ & $\begin{array}{l}\text { (Thiol-C6)CCTGCTGCGTTCTTCTTCAT } \\
\text { CGATGCGAGAGCCAA(Thiol-C3) } \\
\text { (Thiol-C6)CCTGCTGCGTTCTTC } \\
\text { TTCATCGATGCGAGAGCCAA(Thiol-C3) }\end{array}$ \\
\hline T2 & $\begin{array}{l}\text { 35-mer sequence } \\
\text { corresponding to } \\
\text { fragment from NCBI } \\
\text { GenBank accession } \\
\text { number BD082757 }\end{array}$ & TTGGCTCTCGCATCGATGAAGAACGCAGCGAAATG \\
\hline $\begin{array}{l}\text { M2 } \\
M 2 a \\
M 2 b \\
M 2 c \\
M 2 d \\
M 2 e \\
M 2 f\end{array}$ & $\begin{array}{l}\text { T2 with various } \\
\text { mismatch(es) }\end{array}$ & 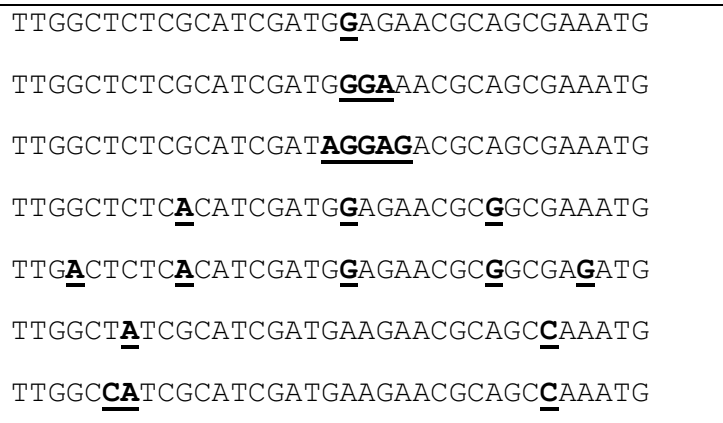 \\
\hline $\begin{array}{l}\mathbf{P} 2 \mathbf{a}^{\mathrm{HTT}} \\
\mathbf{P 2} \mathbf{b}^{\mathrm{HTT}}\end{array}$ & $\begin{array}{l}\text { DNA probes } \\
\text { complementary to T2 } \\
\text { in a head-to-tail } \\
\text { configuration }\end{array}$ & $\begin{array}{l}\text { Alkylhiol linker Poly-GC Binding sequence } \\
\text { (Thiol-C6)GGCCGCGGGCGGCATTTCGCTGCGTTC } \\
\text { (Thiol-C6) CGGGCGGCGCCGTTCATCGATGCGAGAGCCAA }\end{array}$ \\
\hline $\begin{array}{l}\text { P2a }{ }^{T T} \\
P 2 b^{T T T}\end{array}$ & $\begin{array}{l}\text { DNA probes for tail-to- } \\
\text { tail configuration }\end{array}$ & $\begin{array}{l}\text { (Thiol-C6)CATTTCGCTGCGTTC } \\
\text { TTCATCGATGCGAGAGCCAA(Thiol-C3) }\end{array}$ \\
\hline NC & $\begin{array}{l}\text { Non-complementary } \\
\text { DNA }\end{array}$ & GGAAGGCCAGCTACAACCCAGCTAGTCAAGGTAAC \\
\hline
\end{tabular}




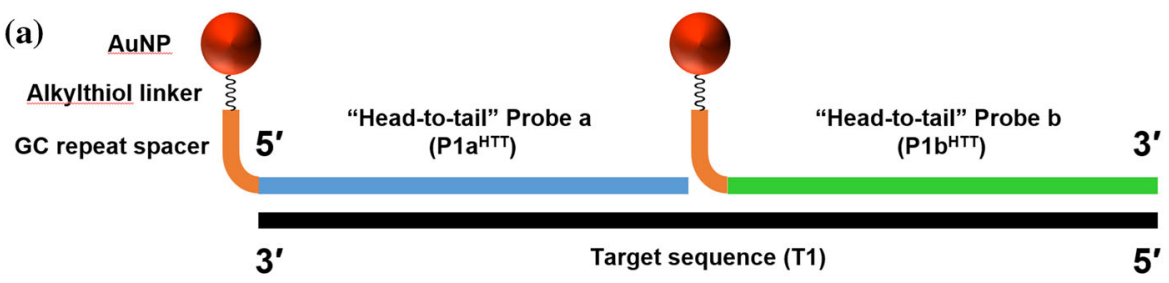

(b) Alkylthiol linker

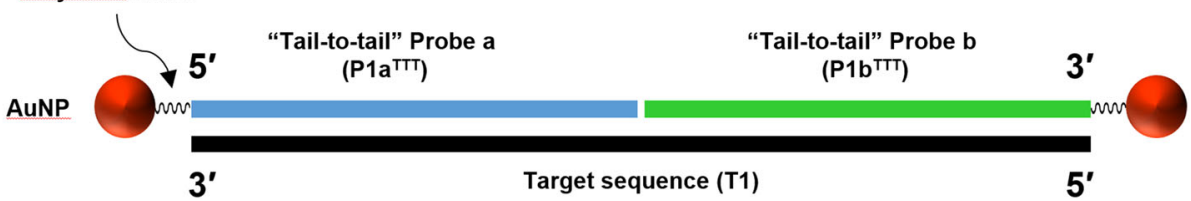

Figure 1 Schematic diagrams illustrating the a head-to-tail (HTT) and $\mathbf{b}$ tail-to-tail (TTT) binding configurations of the DNA-AuNP conjugate probes to the complementary target single-stranded DNA. For brevity, only one example is shown for each configuration: $\mathrm{P} 1 \mathrm{a}^{\mathrm{HTT}}$ and $\mathrm{P} 1 \mathrm{~b}^{\mathrm{HTT}}$ in $(\mathrm{a})$; or $\mathrm{P} 1 \mathrm{a}^{\mathrm{TTT}}$ and $\mathrm{P} 1 \mathrm{~b}^{\mathrm{TTT}}$ in (b). Both pairs of probes are complementary to the $\mathrm{T} 1$ target sequence.
Figure 2 UV-Vis absorption spectra of conjugates prepared using probes a $\mathrm{P} 1 \mathrm{a}^{\mathrm{HTT}}$ and $\mathrm{P} 1 \mathrm{~b}^{\mathrm{HTT}}, \mathbf{b} \mathrm{P} 2 \mathrm{a}^{\mathrm{HTT}}$, and $\mathrm{P} 2 \mathrm{~b}^{\mathrm{HTT}}$. (a)

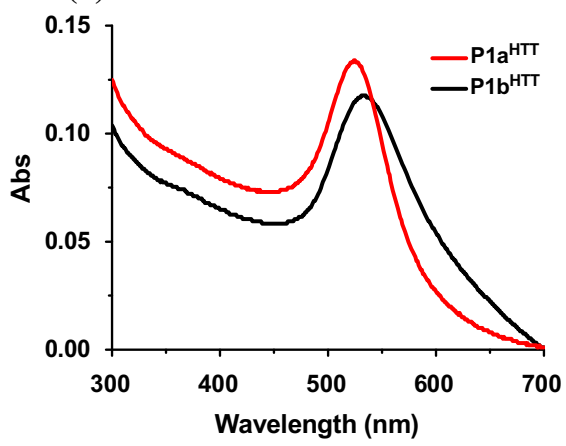

(b)

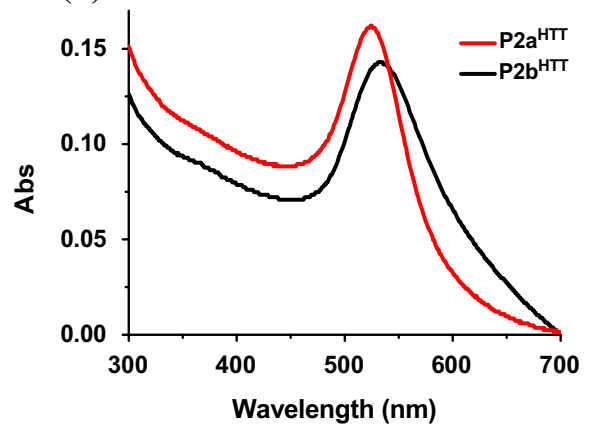

$\left(\mathrm{P} 1 \mathrm{a}^{\mathrm{TTT}}\right.$ and $\mathrm{P} 1 \mathrm{~b}^{\mathrm{TTT}}, \mathrm{P} 1 \mathrm{c}^{\mathrm{TTT}}$, and $\left.\mathrm{P} 1 \mathrm{~d}^{\mathrm{TTT}}\right)$ were prepared (Table 1). For sequence T2, one pair of each conjugate was prepared for each configuration $\left(\mathrm{P} 2 \mathrm{a}^{\mathrm{HTT}}\right.$ and $\mathrm{P} 2 \mathrm{~b}^{\mathrm{HTT}}, \mathrm{P} 2 \mathrm{a}^{\mathrm{TTT}}$, and P2b ${ }^{\text {TTT }}$; Table 1$)$.

Following their preparation, the DNA-AuNP conjugate bearing the $\mathrm{P} 1 \mathrm{a}^{\mathrm{HTT}}$ probe exhibited the expected deep red colour and a corresponding UVVis spectrum with a $\lambda_{\max }$ at $525 \mathrm{~nm}$ (Fig. 2a), similar to $\lambda_{\max }$ for unconjugated AuNP. However, for P1b ${ }^{\text {HTT }}$, a higher $\lambda_{\max }(533 \mathrm{~nm})$ and a broad tail towards the higher wavelengths was observed, which suggests the presence of aggregated AuNPs. DNA-AuNP colloids bearing the P2a ${ }^{\text {HTT }}$ and P2 $b^{\text {HTT }}$ probes also showed similar results (Fig. $2 \mathrm{~b}$ ), with P2 $b^{\text {HTT }}$ showing a broad tail along with $\lambda_{\max }$ at $533 \mathrm{~nm}$. Both pairs of probes were thus unsuitable for further investigation.

Probes in the tail-to-tail configuration were then prepared, starting with the P1a ${ }^{\mathrm{TTT}}$ and $\mathrm{P} 1 \mathrm{~b}^{\mathrm{TTT}}$ pair. After DNA conjugation, the expected red colour and a $\lambda_{\max }$ of $525 \mathrm{~nm}$ were observed for colloid bearing the P1 $\mathrm{a}^{\mathrm{TTT}}$ probe (Fig. 3a). However, despite several efforts to produce the conjugates of $\mathrm{P} 1 \mathrm{~b}^{\mathrm{TTT}}$ under various conditions, stable colloids could not be produced. The AuNPs precipitated during the $\mathrm{NaCl}$ addition step, resulting in only minimal amounts of suspended conjugates, as evidenced by the minimal UV-Vis absorbance. An alternative design was then attempted using the same sequence that was complementary to the T1 target sequence, but now differently divided into each probe (referenced as P1c ${ }^{\text {TTT }}$ and P1d ${ }^{\text {TTT }}$; Table 1). This revised design led to the successful preparation of the DNA-AuNP conjugates with the expected optical properties (Fig. 3b). Based on these results, probes $\mathrm{P} 2 \mathrm{a}^{\mathrm{TTT}}$ and P2 $b^{\text {TTT }}$ were designed for T2 (Table 1), and the prepared conjugates were found to display the expected optical properties (Fig. 3c).

It was found that the prepared DNA-AuNP conjugates $\left(\mathrm{P} 1 \mathrm{c}^{\mathrm{TTT}}, \mathrm{P} 1 \mathrm{~d}^{\mathrm{TTT}}, \mathrm{P} 2 \mathrm{a}^{\mathrm{TTT}}\right.$, and $\left.\mathrm{P} 2 \mathrm{~b}^{\mathrm{TTT}}\right)$ were 
Figure 3 UV-Vis absorption spectra of conjugates prepared using probes a $\mathrm{P} 1 \mathrm{a}^{\mathrm{TTT}}$ and $\mathrm{P}_{1} \mathrm{~b}^{\mathrm{TTT}}, \mathbf{b}$ P $1 \mathrm{c}^{\text {TTT }}$ and P1d $\mathrm{d}^{\text {TTT }}$ and $\mathrm{c} \mathrm{P} 2 \mathrm{a}^{\mathrm{TTT}}$ and $\mathrm{P} 2 \mathrm{~b}^{\mathrm{TTT}}$.
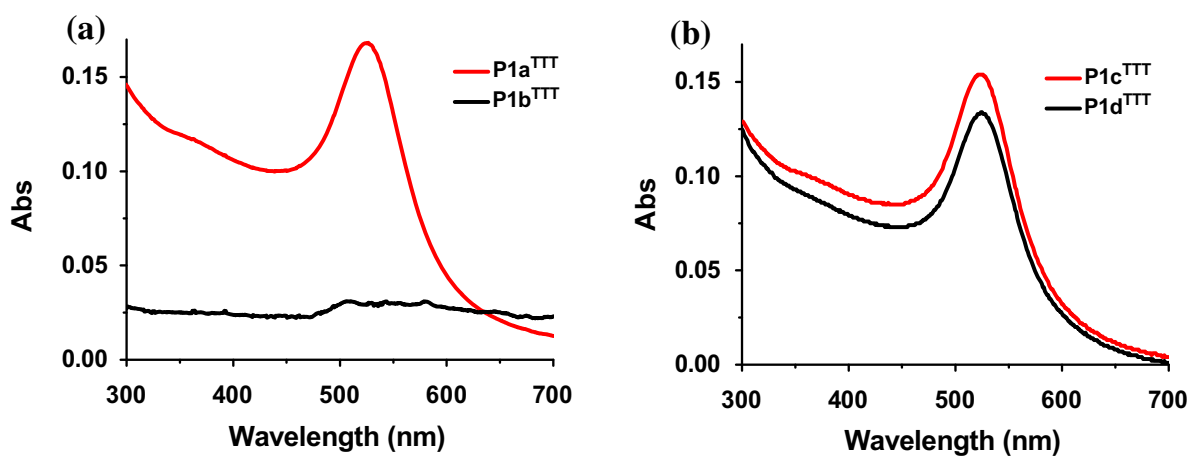

stable between a $\mathrm{pH}$ of 4 and 7 , as evidenced by a lack of change in the UV-Vis spectra. Further, these conjugates were stable for up to two months if stored at $4{ }^{\circ} \mathrm{C}$ (at pH 7), though only for 3-4 days if stored at room temperature (in the UK, approximately $20^{\circ} \mathrm{C}$ ), as evidenced by UV-Vis spectroscopy.

These results suggest that to achieve stable conjugates, a minimum of 20 bases are required when DNA is conjugated to AuNP at $3^{\prime}$ position of DNA, though the reason for this observation is unclear. The $\mathrm{P} 1 \mathrm{~b}^{\mathrm{TTT}}$ probe has been previously used successfully in other sensor platforms [19], but the current result nevertheless shows that the cross-compatibility of DNA probes between different applications cannot be assumed. Thus, the probe pair $\mathrm{P} 1 \mathrm{c}^{\mathrm{TTT}} / \mathrm{P} 1 \mathrm{~d}^{\mathrm{TTT}}$ complementary to T1, and $\mathrm{P} 2 \mathrm{a}^{\mathrm{TTT}} / \mathrm{P} 2 \mathrm{~b}^{\mathrm{TTT}}$ pair complementary to $\mathrm{T} 2$ were taken for further evaluation.

\section{Hybridisation against single-stranded DNA}

In preliminary optimisation experiments, the hybridisation assays were carried out with ssDNA sequences as the analyte, which was added to a mixture consisting of each pair of complementary DNA-AuNP probes. Three types of analytes were tested (Table 1): (1) the 35-base target DNA strand fully complementary to their respective probes (i.e. either T1 or T2); (2) DNA sequences containing a

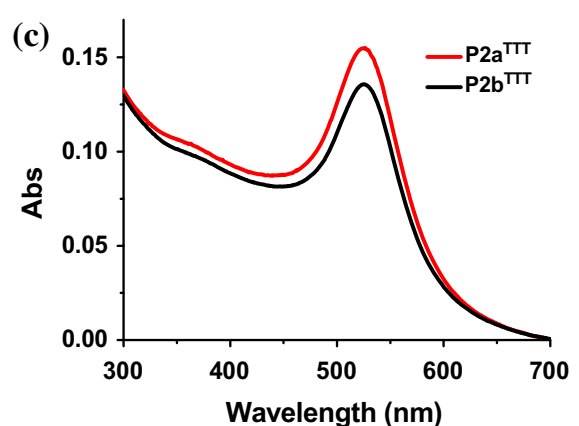

single base mismatch referred to as M1 and M2, but otherwise, identical to $\mathrm{T} 1$ or $\mathrm{T} 2$, respectively; (3) "non-complementary" DNA consisting of a randomly generated sequence of identical length and similar GC content to T1 and T2 (termed NC). In all cases, a mixture of equivalent concentrations of DNA-AuNP conjugates was prepared (to an OD of $0.7 @ 525 \mathrm{~nm}$ of each probe prior to mixing), to which the ssDNA analyte was added to give a final analyte concentration of $1 \mu \mathrm{M}$ (corresponding to $200 \mathrm{pmol}$ of analyte in $200 \mu \mathrm{L}$ of the total assay mixture). In the negative control, only water was added as the analyte (henceforth referred to as " $\mathrm{C}$ " in all figures).

For the hybridisation experiments with the tail-totail configuration using probes $\mathrm{P} 1 \mathrm{c}^{\mathrm{TTT}}$ and $\mathrm{P} 1 \mathrm{~d}^{\mathrm{TTT}}$ against $\mathrm{T} 1$, it was found that a hybridisation mixture with $1 \mathrm{M} \mathrm{NaCl}$ gave good hybridisation after $30 \mathrm{~min}$. This result was evidenced by a visually observable colour change from a deep red to lilac and was corroborated by the UV-Vis spectrum that exhibited a $\lambda_{\max }$ increase from 525 to $550 \mathrm{~nm}$, a decrease in the absorbance at their respective $\lambda_{\max }\left(A_{\max }\right)$ from 0.6 to 0.1 (an approximately $80 \%$ reduction), and a broadening of the peak (Fig. 4a, b). In contrast, a negative control experiment where only water was added, no significant change in colour or the UV-Vis spectrum was observed. Similarly, the NC sequence gave no 
Figure 4 Photographs and $\mathrm{UV}-\mathrm{Vis}$ spectra of the assay mixtures containing the DNAAuNP conjugates and analyte for: $\mathbf{a}, \mathbf{b}$ mixtures using $\mathrm{P} 1 \mathrm{c}^{\mathrm{TTT}}$ and P1d $\mathrm{d}^{\mathrm{TTT}}$ probes; and $\mathbf{c}, \mathbf{d}$ mixtures using $\mathrm{P} 2 \mathrm{a}^{\mathrm{TTT}}$ and $\mathrm{P} 2 \mathrm{~b}^{\mathrm{TTT}}$ probes.

The key to the figure: $\mathrm{C}=$ negative control (buffer only, no DNA); T1, T2, M1, $\mathrm{M} 2$ and $\mathrm{NC}$ correspond to samples containing the analyte DNA listed in Table 1. The photographs show each assay carried out at a $200 \mu \mathrm{L}$ total volume. (a)

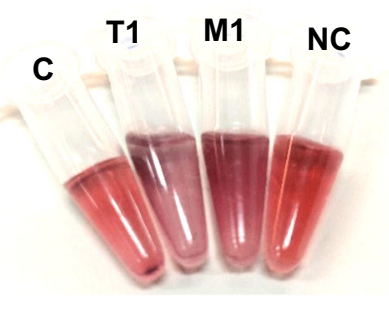

(c)

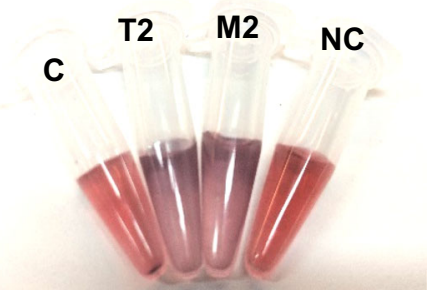

(b)

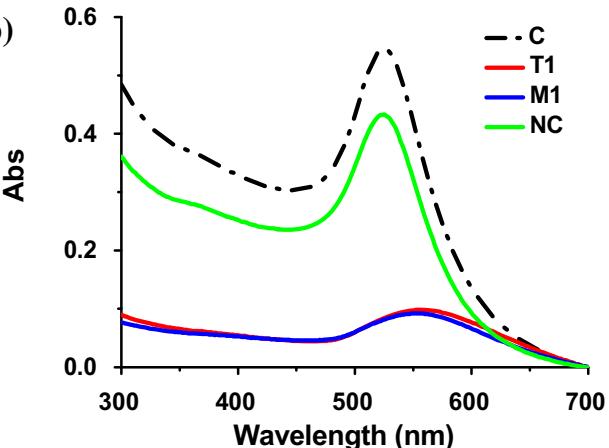

(d)

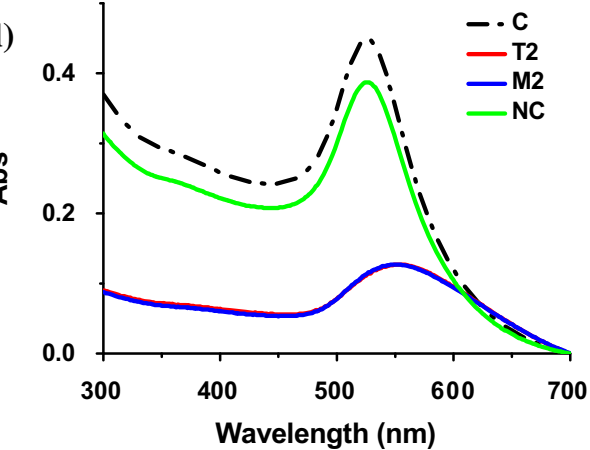

significant change also, which confirms that probe binding is sequence specific. In the case of the mismatched sequence M1, a result similar to T1 was observed, which indicates this probe pair was able to bind and cannot differentiate this single mismatch from the fully complementary sequence (i.e. this is a false positive result).

A similar experiment was performed for $\mathrm{P} 2 \mathrm{a}^{\mathrm{TTT}}$ and $\mathrm{P} 2 \mathrm{~b}^{\mathrm{TTT}}$ probes, against $\mathrm{T} 2$ or $\mathrm{M} 2$. Both these analyte sequences gave colour and spectroscopic changes corresponding to a positive result similar to the above (Fig. 4c, d). As before, negative controls consisting of the NC sequence or water only gave no change.

\section{Response time of hybridisation assay}

The rapidity of the assay was then investigated. Here, using probes $\mathrm{P} 2 \mathrm{a}^{\mathrm{TTT}}$ and $\mathrm{P} 2 \mathrm{~b}^{\mathrm{TTT}}$ against $\mathrm{T} 2$, it was found that a change in $\lambda_{\max }$ from 525 to $548 \mathrm{~nm}$, and decrease in the $A_{\max }$ from 0.7 to 0.2 , occurred after 15 min (Fig. 5c), with little further change even after $45 \mathrm{~min}$ (Fig. 5). This result thus shows that the 30-min incubation time previously used was, in fact, unnecessary, and thus, all subsequent assays were analysed after $15 \mathrm{~min}$.
Assay sensitivity against single-stranded DNA analyte

Based on the above results, DNA analyte T2 and DNA-AuNP conjugates prepared using probes $\mathrm{P} 2 \mathrm{a}^{\mathrm{TTT}}$ and $\mathrm{P} 2 \mathrm{~b}^{\mathrm{TTT}}$ were taken for further study. A series of assays were carried out by adding between 0.1 and 10 pmol of $\mathrm{T} 2$ to the conjugates to test its sensitivity. These results were compared with a positive control with 200 pmol and negative control with water as the analyte. It was found that a visually observable colour change was produced with as little as 0.2 pmol of T2 (Fig. 6a), although the UV-Vis analysis showed that the $\lambda_{\max }$ shift for this amount of analyte was smaller than for the higher amounts (10 nm vs. $25 \mathrm{~nm}$, Fig. 6b). The UV-Vis spectrum corresponding to $0.1 \mathrm{pmol}$ of $\mathrm{T} 2$ did show an $\sim 50 \%$ reduction in $A_{\max }$ without an accompanying change of $\lambda_{\text {max }}$, but this change could not be readily observed visually. Nevertheless, the overall visual transition is very sharp, spanning just one order of magnitude in the pmol-fmol range (i.e. 1.0 pmol was clearly positive, but 0.1 pmol was clearly negative), which equates to concentrations between 5 and $0.5 \mathrm{nM}$. 
Figure 5 a UV-Vis spectra of the assay mixtures containing the DNA-AuNP conjugates and target DNA analyte for $\mathrm{P} 2 \mathrm{a}^{\text {TTT }}$ and $\mathrm{P} 2 \mathrm{~b}^{\text {TTT }}$ probes and b a graph of the corresponding $\lambda_{\text {max }}$ versus time. The photographs show $\mathrm{C}$ and $\mathrm{T} 2$ DNA analyte (200 pmol) assays after 1 and $15 \mathrm{~min}$ (c and $\mathbf{d}$, respectively). (a)

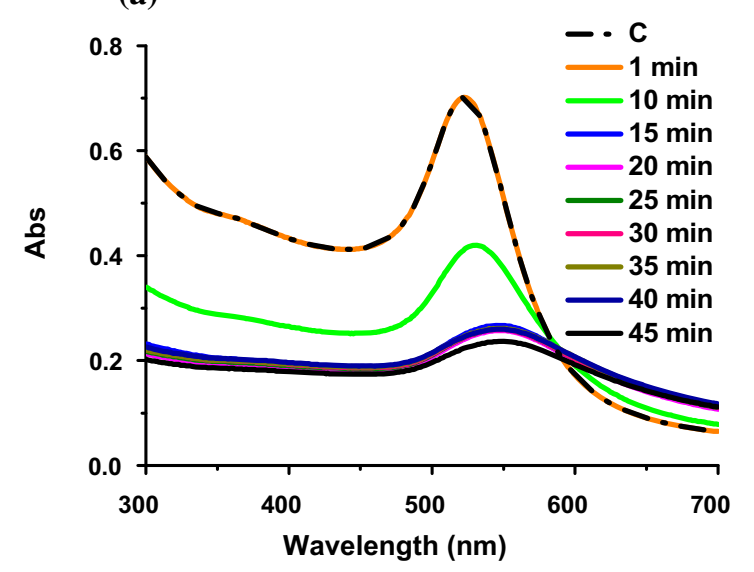

(b)

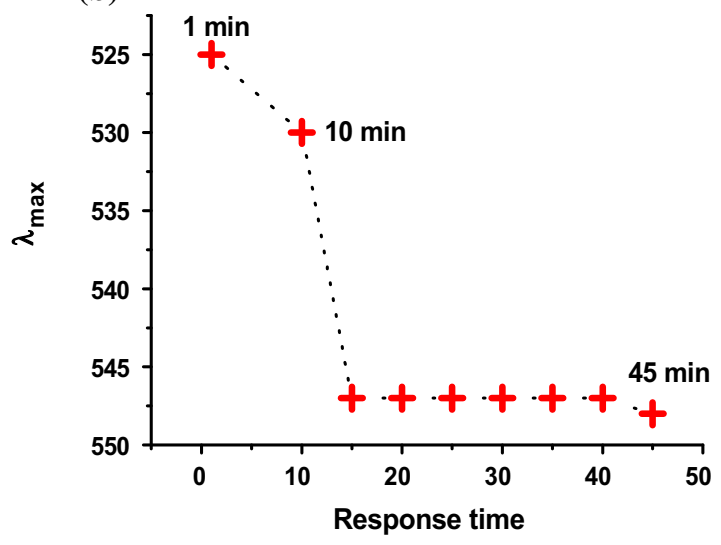

(c)

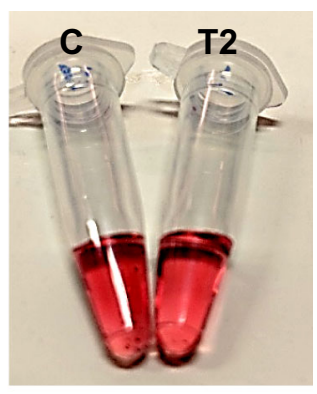

(a)

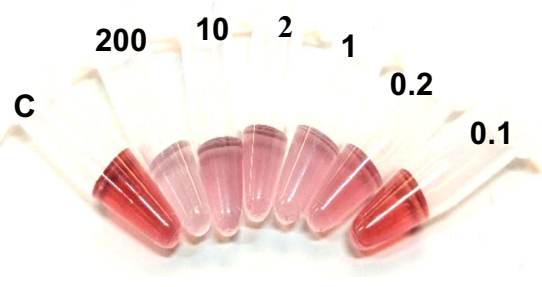

(b)

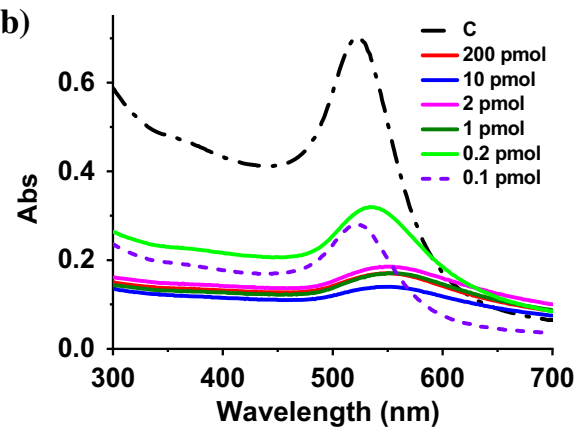

Figure 6 a Photograph and $\mathbf{b}$ UV-Vis spectra of the assay mixtures containing the DNA-AuNP conjugates $\mathrm{P} 2 \mathrm{a}^{\mathrm{TTT}}$ and $\mathrm{P} 2 \mathrm{~b}^{\mathrm{TTT}}$ and varying amounts of T2. The photograph shows each

assay carried out at a $200 \mu \mathrm{L}$ total volume, with the labels indicating the amount of T2 DNA added in pmol.

\section{Effect of mismatches on hybridisation efficiency}

As the results with the single-base mismatch M2 sequence also gave a positive result, the tolerance of the assay (with probes $\mathrm{P} 2 \mathrm{a}^{\mathrm{TTT}} / \mathrm{P} 2 \mathrm{~b}^{\mathrm{TTT}}$ ) against other mismatched sequences was investigated. For this

(d)

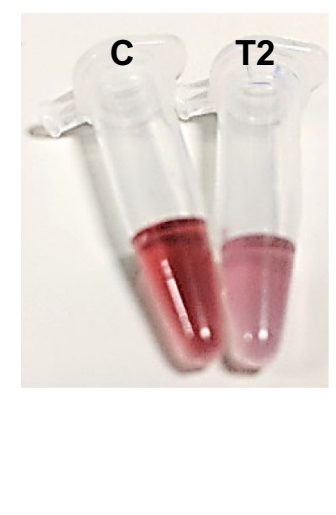

purpose, the assays were carried out with a series of analyte sequences bearing mismatches at multiple locations, referenced M2a to M2f (Table 1).

It was found that analyte sequence M2a, bearing three mismatches in series at the junction where the two probe sequences meet, also gave a false positive. This result was evidenced by a visually observable 
(a)

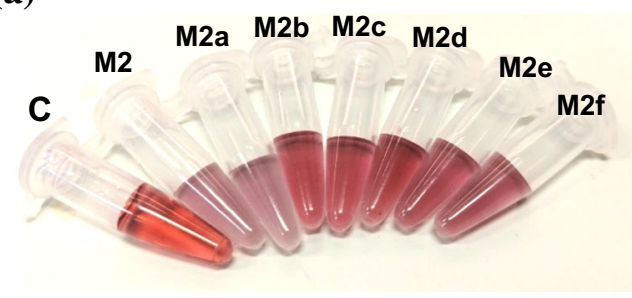

(b)

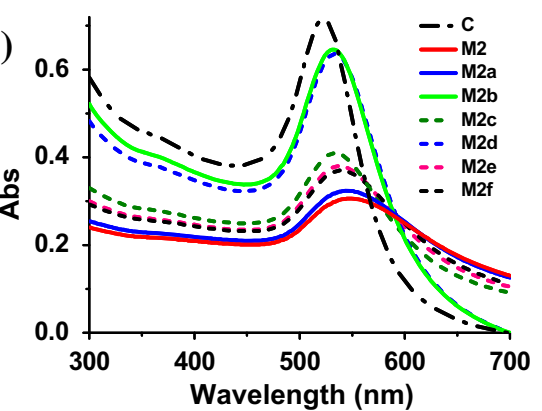

(d)

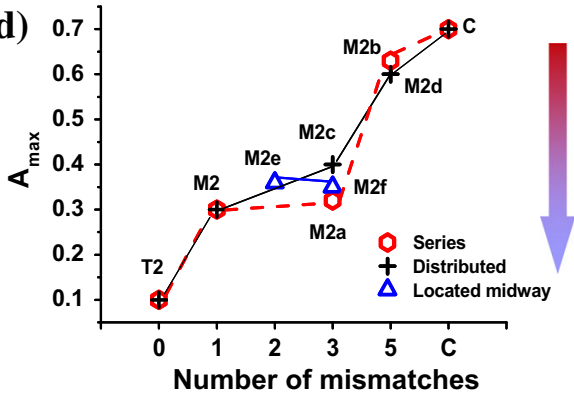

indicates the control reaction where water is added as the analyte). The photograph shows each assay carried out at a $200 \mu \mathrm{L}$ total volume, and the amount of mismatched DNA was kept at 200 pmol for consistency with the results observed for M2 (in "Hybridisation against single-stranded DNA" section).

remaining complementary base pairs. It is known that DNA duplexes with more than $\sim 12$ complementary base pairs typically exhibit melting temperatures $\left(T_{\mathrm{m}}\right)$ well above $37{ }^{\circ} \mathrm{C}$ [36]. Since even three mismatches would allow both probes to bind with $\geq 14$ serial base pairings, it would be expected that stable DNA hybridisation can still be achieved, which translates to a positive result. In comparison, M2c with three distributed mismatches gave a negative result. However, it is notable that five mismatches in series (M2b) gave a negative result, even though it would still theoretically give $>12$ base pairings in series. This result suggests that $\geq 14$ serial base pairings are required in these conjugates, which could be due to the presence of AuNP hindering efficient hybridisation.

In the case of mismatches located midway within the sequence of each probe (M2e and M2f), these gave an ambiguous result that was mid-way between the positive and negative controls. An intermediate colour and intensity change were visually observed, consistent with the UV-Vis spectra that gave a $\lambda_{\max }$ shift to 538 and $536 \mathrm{~nm}$ (for M2e and M2f, 
respectively) and an $A_{\max }$ decrease of $\sim 48 \%$ for both (Fig. 7d). Thus, though these mismatches could not be differentiated by eye, they could still be identified spectroscopically.

Assays based purely on direct hybridisation are known to have a limited ability to discriminate single base-pair mismatches due to the small difference in stability compared to a perfectly matched DNA duplex. Various modifications to the basic strategy such as employing specific interactions between Lambda exonuclease and a chemically modified DNA [37], double-stranded toehold exchange [38], and co-amplification at lower denaturation temperature [39] have been proposed to enhance the sensitivity of the assays towards one or more mismatches. However, these approaches increase the complexity of the assay and make it less suitable for field deployment.

\section{Assays against double-stranded DNA analytes}

As a step towards biologically relevant diagnostics, the assay was next tested against dsDNA fragments. Here, the experiments consisted of dsDNA with the T2 sequence (referred henceforth as $\mathrm{T} 2^{\prime}$ ) and nanoparticle conjugates bearing probes $\mathrm{P} 2 \mathrm{a}^{\mathrm{TTT}}$ and $\mathrm{P} 2 \mathrm{~b}^{\mathrm{TTT}}$. The assay procedure was also modified such that the analyte was heated to $95^{\circ} \mathrm{C}$ to induce the denaturation of the dsDNA [40] and enable subsequent probe hybridisation upon cooling. It was, however, observed that in contrast to ssDNA (see in "Response time of hybridisation assay" section), a more extended waiting period was needed for the assay to develop (30 vs. 15 min with ssDNA).

A range of analyte amounts was then tested from 0.2 to $200 \mathrm{pmol}$ (in a $200 \mu \mathrm{L}$ final assay volume). In order to optimise the sensitivity, the concentration of $\mathrm{NaCl}$ in the assay mixtures were also varied (either 1.0 or $1.2 \mathrm{M}$ ) [41]. It was found that a visually observable positive result could be achieved at 10, and $1 \mathrm{pmol}$ (corresponding to concentrations of $50 \mathrm{nM}$, and $5 \mathrm{nM}$, respectively) of $\mathrm{T}^{\prime}$, at each of the respective $\mathrm{NaCl}$ concentrations (Fig. 8a, c). These observations were supported by UV-Vis spectra showing both the expected increases in $\lambda_{\max }$ and decreases in $A_{\max }$, typically by $20-25 \mathrm{~nm}$ and $40-50 \%$, respectively, depending on the amount of analyte (Fig. 8b, d). However, even the best results obtained here were still fivefold less sensitive than the equivalent experiment with ssDNA. This result is likely due to the competitive rebinding of the analyte ssDNA to its complementary strand upon cooling.

\section{Selectivity in the presence of non- complementary DNA}

In order to demonstrate the selectivity of the assay in the presence of a large amount of non-complementary genomic DNA that would be present in any potential biologically derived sample, the optimised dsDNA assay was then carried out in the presence of calf thymus DNA (CT), as a model mixture of noncomplementary dsDNA with a variety of lengths. Here, varying amounts of $\mathrm{T} 2^{\prime}$ dsDNA from 0.2 to 200 pmol were mixed with $2.6 \mathrm{mg}$ of CT and tested.

Similar to the isolated dsDNA, quantities of $\mathrm{T}^{\prime}$ as low as 10 and 2 pmol (which equates to a concentration of $50 \mathrm{nM}$ and $10 \mathrm{nM}$ ) gave a visually observable result, even in the presence of a considerable amount of CT, at 1 and $1.2 \mathrm{M}$ (Fig. 9a) $\mathrm{NaCl}$ concentration, respectively. The UV-Vis spectra also showed the corresponding $\lambda_{\max }$ increase from 525 to $540 \mathrm{~nm}$, though the $A_{\max }$ reduction, in this case, was more modest at $24 \%$ (Fig. 9b).

\section{Conclusion}

In conclusion, we have demonstrated the detection of DNA fragments associated with $G$. boninense based on the application of sequence-selective aggregation of DNA-AuNP conjugates. A detailed optimisation was performed involving a range of analyte sequences and two assay configurations to detect ssDNA and dsDNA. The target DNA can be easily be visually identified down to a concentration of $0.2 \mathrm{pmol}$ ssDNA or 2 pmol dsDNA. The sensitivity limit was maintained for the dsDNA even in the presence of a large excess of non-complementary DNA. This protocol is simple to implement and is relatively rapid (within $30 \mathrm{~min}$ ), without the need for sophisticated equipment and specialist training. Indeed, only the mixing of several solutions at room temperature and heating to a single temperature is required.

These results represent the first steps towards the development of a nanoparticle-based assay for practical application in tropical agriculture. To this end, there is significant scope further improvement of the assay performance. The reported results were carried 
Figure 8 Photographs and UV-Vis spectra of the assay mixtures containing the DNAAuNP conjugates $\mathrm{P} 2 \mathrm{a}^{\mathrm{TTT}}$ and $\mathrm{P} 2 \mathrm{~b}^{\mathrm{TTT}}$ and varying amounts of $\mathrm{T}^{\prime}$, with $1.0 \mathrm{M}(\mathbf{a}, \mathbf{b})$ or $1.2 \mathrm{M}(\mathbf{c}, \mathbf{d}) \mathrm{NaCl}$. The photographs show each assay carried out at a $200 \mu \mathrm{L}$ total volume, with the labels indicating the amount of $\mathrm{T} 2^{\prime}$ DNA added in pmol. (a)

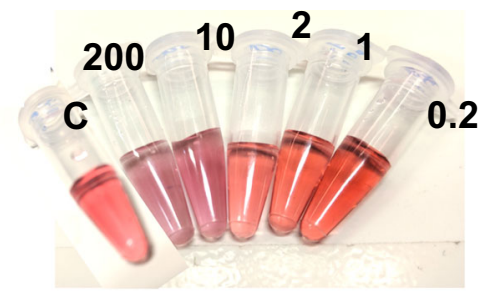

(c)

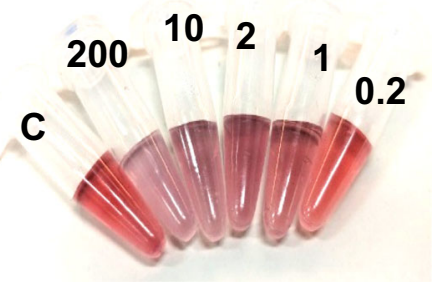

(b)

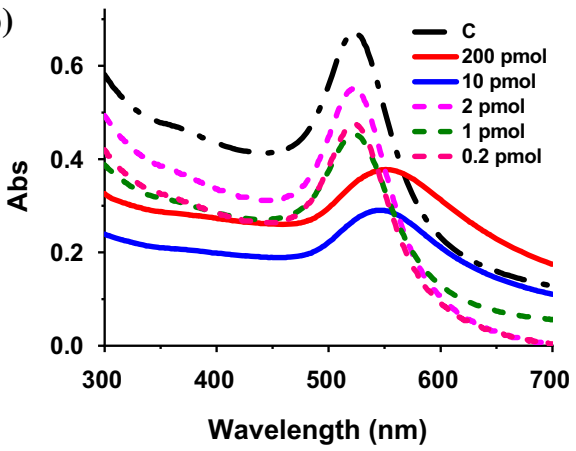

(d)

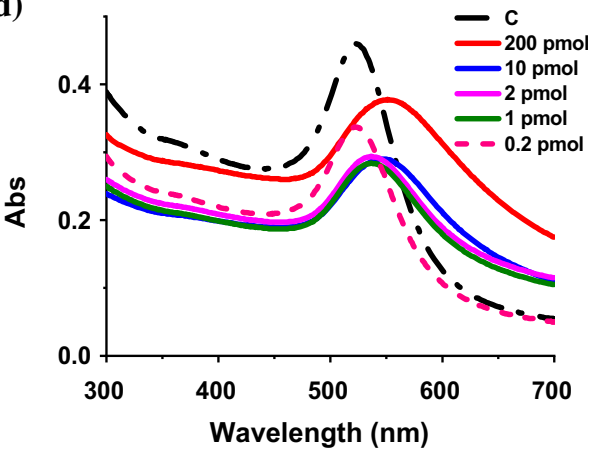

(a)

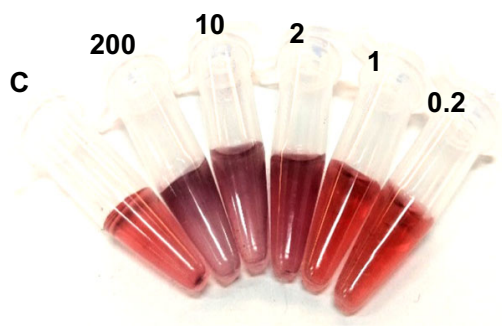

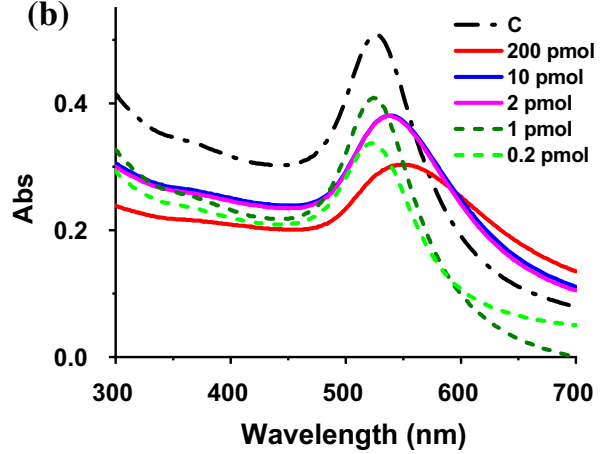

CT with $1.2 \mathrm{M} \mathrm{NaCl}$. The photograph shows each assay carried out at a $200 \mu \mathrm{L}$ total volume, with the labels indicating the amount of $\mathrm{T} 2^{\prime}$ DNA added in pmol.

sequences bearing mismatches [42-45]. The overall sensitivity of the assay could also be improved, especially with respect to dsDNA, through further modification of the basic approach, such as incorporating the capture of the nanoparticle aggregates on surfaces, by increasing the probe/target ratio or by increasing the size of the AuNP used [21, 32].

\section{Acknowledgements}

The authors thank the British Council Newton Fund for support under Contract 216196834, the UK 
Engineering and Physical Sciences Research Council for equipment support under Grants EP/K024485/1, and the HEFCE N8 Agri-food Network for travel funds.

\section{Compliance with ethical standards}

Conflict of interest There are no conflict to declare.

Open Access This article is licensed under a Creative Commons Attribution 4.0 International License, which permits use, sharing, adaptation, distribution and reproduction in any medium or format, as long as you give appropriate credit to the original author(s) and the source, provide a link to the Creative Commons licence, and indicate if changes were made. The images or other third party material in this article are included in the article's Creative Commons licence, unless indicated otherwise in a credit line to the material. If material is not included in the article's Creative Commons licence and your intended use is not permitted by statutory regulation or exceeds the permitted use, you will need to obtain permission directly from the copyright holder. To view a copy of this licence, visit http://creativecommons.org/licen ses/by $/ 4.0 /$.

\section{References}

[1] Nambiappan B, Ismail A, Hashim N et al (2018) Malaysia: 100 years of resilient palm oil economic performance. J Oil Palm Res 30:13-25. https://doi.org/10.21894/jopr.2018.0014

[2] Ho YW, Nawaw A (1985) Ganoderma boninense Pat. from basal stem rot of oil palm (Elaeis guineensis) in Peninsular Malaysia. Pertanika 8:425-428

[3] Paterson RRM (2007) Ganoderma disease of oil palm-A white rot perspective necessary for integrated control. Crop Prot 26:1369-1376. https://doi.org/10.1016/j.cropro.2006.1 1.009

[4] Utomo C, Niepold F (2000) Development of diagnostic methods for detecting ganoderma-infected oil palms. J Phytopathol 148:507-514. https://doi.org/10.1046/j.1439-0434. 2000.00478.x

[5] Hushiarian R, Yusof NA, Dutse SW (2013) Detection and control of Ganoderma boninense: strategies and perspectives. Springerplus 2:1-12. https://doi.org/10.1186/2193-18 01-2-555

[6] Guglielmo F, Bergemann SE, Gonthier P et al (2007) A multiplex PCR-based method for the detection and early identification of wood rotting fungi in standing trees. J Appl
Microbiol 103:1490-1507. https://doi.org/10.1111/j.1365-2 672.2007.03378.x

[7] Ommelna BG, Jennifer AN, Chong KP (2012) The potential of chitosan in suppressing Ganoderma boninense infection in oil-palm seedlings. J Sustain Sci Manag 7:186-192

[8] Markom MA, Shakaff AYM, Adom AH et al (2009) Intelligent electronic nose system for basal stem rot disease detection. Comput Electron Agric 66:140-146. https://doi. org/10.1016/j.compag.2009.01.006

[9] Najmie M, Khalid K, Sidek A, Jusoh M (2011) Density and ultrasonic characterization of oil palm trunk infected by Ganoderma boninense disease. Meas Sci Rev 11:160-164. h ttps://doi.org/10.2478/v10048-011-0026-x

[10] Lelong CCD, Roger JM, Brégand S et al (2010) Evaluation of oil-palm fungal disease infestation with canopy hyperspectral reflectance data. Sensors 10:734-747. https://doi.or $\mathrm{g} / 10.3390 / \mathrm{s} 100100734$

[11] Santoso H, Gunawan T, Jatmiko RH et al (2011) Mapping and identifying basal stem rot disease in oil palms in North Sumatra with QuickBird imagery. Precis Agric 12:233-248. https://doi.org/10.1007/s11119-010-9172-7

[12] Djavanroodi F, Ahmadian H, Naseri R et al (2016) Experimental investigation of ultrasonic assisted equal channel angular pressing process. Arch Civ Mech Eng 16:249-255. h ttps://doi.org/10.1016/j.acme.2015.10.001

[13] Hashim IC, Shariff ARM, Bejo SK et al (2018) Classification for non infected and infected Ganoderma boninense of oil palm trees using ALOS PALSAR-2 backscattering coefficient. IOP Conf Ser Earth Environ Sci 169:012066. h ttps://doi.org/10.1088/1755-1315/169/1/012066

[14] Darmono TW, Suharyanto A (1995) Recognition of field materials of Ganoderma sp. associated with basal stem rot in oil palm by a polyclonal antibody. Menara Perkeb 63:15-22

[15] Shamala S, Chris D, Sioban O, Idris AS (2006) Preliminary studies on the development of monoclonal antibodies against mycelia of Ganoderma boninense, the causal pathogen of basal stem rot of oil palm. Malays J Microbiol 2:30-34. h ttps://doi.org/10.21161/mjm.210605

[16] Madihah AZ, Idris AS, Rafidah AR (2014) Polyclonal antibodies of Ganoderma boninense isolated from Malaysian oil palm for detection of basal stem rot disease. Afr J Biotechnol 13:3455-3463. https://doi.org/10.5897/AJ B2013.13604

[17] Akanbi FS, Yusof NA, Abdullah J et al (2017) Detection of quinoline in $G$. boninense-infected plants using functionalized multi-walled carbon nanotubes: a field study. Sensors 17:1538. https://doi.org/10.3390/s17071538

[18] Dutse SW, Yusof NA, Ahmad H et al (2014) An electrochemical biosensor for the determination of Ganoderma boninense pathogen based on a novel modified gold 
nanocomposite film electrode. Anal Lett 47:819-832. http s://doi.org/10.1080/00032719.2013.858261

[19] Hushiarian R, Yusof NA, Abdullah AH et al (2015) Facilitating the indirect detection of genomic DNA in an electrochemical DNA biosensor using magnetic nanoparticles and DNA ligase. Anal Chem Res 6:17-25. https://doi.org/10.10 16/j.ancr.2015.10.004

[20] Elghanian R, Storhoff JJ, Mucic RC et al (1997) Selective colorimetric detection of polynucleotides based on the distance-dependent optical properties of gold nanoparticles. Science (80-) 277:1078-1081. https://doi.org/10.1126/scien ce. 277.5329 .1078

[21] Storhoff JJ, Lucas AD, Garimella V et al (2004) Homogeneous detection of unamplified genomic DNA sequences based on colorimetric scatter of gold nanoparticle probes. Nat Biotechnol 22:883-887. https://doi.org/10.1038/nbt977

[22] Li F, Zhang H, Dever B et al (2013) Thermal stability of DNA functionalized gold nanoparticles. Bioconjug Chem 24:1790-1797. https://doi.org/10.1021/bc300687z

[23] Valentini P, Pompa PP (2013) Gold nanoparticles for nakedeye DNA detection: smart designs for sensitive assays. RSC Adv 3:19181-19190. https://doi.org/10.1039/c3ra43729a

[24] Li G, Zhu L, Wu Z et al (2016) Digital concentration readout of DNA by absolute quantification of optically countable gold nanorods. Anal Chem 88:10994-11000. https://d oi.org/10.1021/acs.analchem.6b02712

[25] Wu Z, Yang R, Zu D, Sun S (2017) Microscopic differentiation of plasmonic nanoparticles for the ratiometric readout of target DNA. Sci Rep 7:1-9. https://doi.org/10.1038/ s41598-017-15256-1

[26] Jyoti A, Pandey P, Pal Singh S et al (2010) Colorimetric detection of nucleic acid signature of shiga toxin producing Escherichia coli using gold nanoparticles. J Nanosci Nanotechnol 10:4154-4158. https://doi.org/10.1166/jnn.2010. 2649

[27] Tan YN, Lee KH, Su X (2011) Study of single-stranded DNA binding protein-nucleic acids interactions using unmodified gold nanoparticles and its application for detection of single nucleotide polymorphisms. Anal Chem 83:4251-4257. https://doi.org/10.1021/ac200525a

[28] Tan YN, Lee KH, Su X (2013) A study of DNA design dependency of segmented DNA-induced gold nanoparticle aggregation towards versatile bioassay development. RSC Adv 3:21604-21612. https://doi.org/10.1039/c3ra44661a

[29] Liang K, Zhai S, Zhang Z et al (2014) Ultrasensitive colorimetric carcinoembryonic antigen biosensor based on hyperbranched rolling circle amplification. Analyst 139:4330-4334. https://doi.org/10.1039/c4an00417e

[30] Chen C, Luo M, Ye T et al (2015) Sensitive colorimetric detection of protein by gold nanoparticles and rolling circle amplification. Analyst 140:4515-4520. https://doi.org/10.10 $39 / \mathrm{c} 5 \mathrm{an} 00485 \mathrm{c}$

[31] Li F, Wang J, Lai Y et al (2013) Ultrasensitive and selective detection of copper (II) and mercury (II) ions by dye-coded silver nanoparticle-based SERS probes. Biosens Bioelectron 39:82-87. https://doi.org/10.1016/j.bios.2012.06.050

[32] Rani E, Mohshim SA, Ahmad MZ et al (2019) Polymer pen lithography-fabricated DNA arrays for highly sensitive and selective detection of unamplified Ganoderma boninense DNA. Polymers (Basel) 11:561. https://doi.org/10.3390/ polym 11030561

[33] Sakamoto A, Mikawa T, Murase M, Tanaka A, Kuran R (2001) Method for detecting a disease germ of oil palm, Ganoderma boninense and detection primer. Patent JP 2001314199-A1

[34] Badotti F, De Oliveira FS, Garcia CF et al (2017) Effectiveness of ITS and sub-regions as DNA barcode markers for the identification of Basidiomycota (Fungi). BMC Microbiol 17:1-12. https://doi.org/10.1186/s12866-017-0958-x

[35] Sun W, Jiang T, Lu Y et al (2014) Cocoon-like selfdegradable DNA nanoclew for anticancer drug delivery. J Am Chem Soc 136:14722-14725. https://doi.org/10.1021/ ja5088024

[36] de Bruin D, Bossert N, Aartsma-Rus A, Bouwmeester D (2018) Measuring DNA hybridization using fluorescent DNA-stabilized silver clusters to investigate mismatch effects on therapeutic oligonucleotides. J Nanobiotechnol 16:1-8. https://doi.org/10.1186/s12951-018-0361-2

[37] Wu T, Xiao X, Zhang Z, Zhao M (2015) Enzyme-mediated single-nucleotide variation detection at room temperature with high discrimination factor. Chem Sci 6:1206-1211. h ttps://doi.org/10.1039/c4sc03375b

[38] Chen SX, Zhang DY, Seelig G (2013) Conditionally fluorescent molecular probes for detecting single base changes in double-stranded DNA. Nat Chem 5:782-789. https://doi.org/ 10.1038/nchem. 1713

[39] Li J, Wang L, Mamon H et al (2008) Replacing PCR with COLD-PCR enriches variant DNA sequences and redefines the sensitivity of genetic testing. Nat Med 14:579-584. h ttps://doi.org/10.1038/nm1708

[40] Wang X, Lim HJ, Son A (2014) Characterization of denaturation and renaturation of DNA for DNA hybridization. Environ Health Toxicol 29:e2014007. https://doi.org/10.56 20/eht.2014.29.e2014007

[41] Sato K, Hosokawa K, Maeda M (2003) Rapid aggregation of gold nanoparticles induced by non-cross-linking DNA hybridization. J Am Chem Soc 125:8102-8103. https://doi. org/10.1021/ja034876s

[42] Xu G, Lai M, Wilson R et al (2019) Branched hybridization chain reaction-using highly dimensional DNA 
nanostructures for label-free, reagent-less, multiplexed molecular diagnostics. Microsyst Nanoeng 5:37. https://doi. org/10.1038/s41378-019-0076-Z

[43] Wang JY, Liu Y, Hofmann S, Kovac J (2012) Influence of nonstationary atomic mixing on depth resolution in sputter depth profiling. Surf Interface Anal 44:569-572. https://doi. org/10.1002/sia.3855

[44] Yao D, Song T, Sun X et al (2015) Integrating DNA-stranddisplacement circuitry with self-assembly of spherical nucleic acids. J Am Chem Soc 137:14107-14113. https://d oi.org/10.1021/jacs.5b07453

[45] Song T, Xiao S, Yao D et al (2014) An efficient DNA-fueled molecular machine for the discrimination of single-base changes. Adv Mater 26:6181-6185. https://doi.org/10.1002 /adma.201402314

Publisher's Note Springer Nature remains neutral with regard to jurisdictional claims in published maps and institutional affiliations. 